Angiotensin converting enzyme inhibition reveals an important role for the Anin system in the control of normal and high blood pressure in man. Clin Exp Hypertens [A] 1983;5:1367-80.

25 Anderson S, Rennke HG, Garcia DL, Brenner BM. Short and long term effects of antihypertensive therapy in the diabetic rat. Kidney Int 1989;36: 526-36.

26 Hall JE, Guyton AC, Jackson TE, Coleman TG, Lohmeier TE, Tripoddo NC. Control of glomerular filtration rate by renin-angiotensin system. Am $\mathcal{f}$ Physiol 1977;233:F366-72.

27 Franken AAM, Derkx FHM, Man in't Veld, Hop WCJ, van Rens GH, Peperkamp E, et al. High plasma prorenin in diabetes mellitus and its correlation with some complications. I Clin Endocrinol Metab 1990;71: 1008-15.

28 Marre M, Hallab M, Billiard A, Le Jeune JJ, Bled F, Girault A, et al. Small doses of ramipril to reduce microalbuminuria in diabetic patients with incipient nephropathy independently of blood pressure changes. f Cardiovasc Pharmacol 1991:18:S165-8.

29 Pedersen MM, Schmitz A, Pedersen EB, Danielsen H, Christiansen JS. Acute and long-term renal effects of angiotensin converting enzyme inhibition in normotensive, normoalbuminuric insulin-dependent diabetic patients. Diabetic Med 1988;5:562-9.

30 Rudberg S, Aperia A, Freyschuss U, Persson B. Enalapril reduces microalbuminuria in young normotensive type 1 (insulin-dependent) diabetic patients irrespective of its hypotensive effect. Diabetologia 1990;33:470-6.
31 Morelli E, Loon N, Meyer T, Peters W, Myers BD. Effects of converting enzyme inhibition on barrier function in diabetic glomerulopathy. Diabetes 1990;39:76-82.

32 Christensen CK, Mogensen CE. Effect of antihypertensive treatment on progression of incipient diabetic nephropathy. Hypertension 1985;7 (suppl II):109-13.

33 Björk S, Mulec H, Hohnsen SA, Nyberg G, Aurell M. Contrasting effects of enalapril and metoprolol on proteinuria in diabetic nephropathy. $B M F$ 1990;300:904-7.

34 Mimram A, Insua A, Ribstein J, Bringer J, Monnier L. Comparative effects of captopril and nifedipine in normotensive patients with incipient diabetic nephropathy. Diabetes Care 1988:11:850-3.

35 Romanelli G, Giustina A, Bossoni S, Caldonazzo A, Cimino A, Cravarezza P, et al. Short-term administration of captopril and nifedipine and exerciseinduced albuminuria in normotensive diabetic patients with early-stage nephropathy. Diabetes 1990;39:1333-8.

36 Hannedouche T, Delgado A, Gnionsahe A, Boitard C, Lacour B, Grunfeld JP. Renal hemodynamics and segmental tubular reabsorption in early type 1 diabetes. Kidney Int 1990;37:1126-33.

37 Björck S, Mulec H, Johnson SA, Norden G, Aurell M. Renal protective effect of enalapril in diabetic nephropathy. BMF 1992;304:339-43.

(Accepted 30 October 1992)

\title{
Epidemiology of endometriosis in women attending family planning clinics
}

\author{
M P Vessey, L Villard-Mackintosh, R Painter
}

\section{Abstract}

Objective-To describe the epidemiology of endometriosis in women attending family planning clinics with special reference to contraceptive methods.

Design-Non-randomised cohort study with follow up of subjects for up to 23 years. Disease was measured by first hospital admission rates since endometriosis can be diagnosed with accuracy only at laparotomy or laparoscopy.

Setting-17 family planning centres in England and Scotland.

Subjects-17032 married white women aged 25-39 years at entry during 1968-74 who were taking oral contraceptives or using an intrauterine device or diaphragm. About $99 \%$ of the women approached agreed to participate and annual loss to follow up was about $0 \cdot 3 \%$.

Main outcome measures-Diagnosis of endometriosis, age, parity, and history of contraceptive use.

Results-Endometriosis was significantly related to age, peaking at ages $40-44\left(\chi^{2}\right.$ for heterogeneity= $30.9, p<0.001)$. Endometriosis was not linked to duration of taking oral contraceptives. Nevertheless, the risk of endometriosis was low in women currently taking oral contraceptives (relative risk $0.4 ; 95 \%$ confidence interval 0.2 to 0.7 ), but higher in women who had formerly taken them $(1 \cdot 8 ; 1.0$ to $3 \cdot 1$ in women who had stopped 25-48 months previously) compared with women who had never taken the pill. A similar pattern was seen for use of intrauterine devices (relative risk $0.4(0.2$ to 0.7$)$ in current users and $1.4(0.4$ to 3.2$)$ in users $49-72$ months previously compared with never users). No association was found between endometriosis and use of the diaphragm.

Department of Public Health and Primary Care, Radeliffe Infirmary, Oxford OX2 6HE

M P Vessey, professor

L Villard-Mackintosh, research officer

R Painter, computer scientist

Correspondence to:

Professor Vessey.

Conclusions-Oral contraceptives seem to temporarily suppress endometriosis. Endometriosis may be diagnosed late in women using intrauterine devices as pain and bleeding occur with both.

\section{Introduction}

Endometriosis is a condition in which there is functioning endometrial tissue outside the uterine cavity.' The disease process is usually limited to the pelvis and clinical manifestations include pain, menstrual disorders, infertility, and pelvic masses. Diagnosis by clinical methods is unreliable and confirmation is required by laparoscopy or laparotomy.

In view of the lack of epidemiological information about endometriosis, we decided to analyse the available data in the Oxford Family Planning Association contraceptive study.

\section{Subjects and methods}

The methods used in the Oxford Family Planning Association study have been described in detail elsewhere. ${ }^{2}$ In brief, 17032 women were recruited at 17 large family planning clinics in England and Scotland during 1968-74. To be eligible for the study women had to be white, British, married, aged 25-39 years, and to have been taking oral contraceptives for at least five months, or using a diaphragm or intrauterine device for at least five months without previous exposure to oral contraceptives. About $99 \%$ of those approached consented to participate in the study and follow up is still continuing.

At return visits to the clinic women are questioned by a doctor or a nurse and the information recorded on a special form, including details of pregnancies and their outcome, changes in contraceptive practices, and reasons for referral to hospital. Women who stop attending the clinic are sent a postal version of the questionnaire and, if this is not returned, are interviewed over the telephone or at a home visit. Each hospital admission is followed up by writing to the consultant concerned to obtain a copy of the discharge summary. The work in each clinic is coordinated by a part time research assistant, and follow up has been maintained with an annual loss because of withdrawal of cooperation or loss of contact of only about $0.3 \%$. Only women who have never taken the pill and those who have taken it for eight or more years are followed up beyond the age of 45 .

The study collects detailed morbidity information only about illnesses requiring referral to hospital. This was not a limitation in this analysis because endometriosis has to be diagnosed by laparoscopy or laparotomy. The numbers of cases per 1000 woman years of observation in the various groups were compared. Rates of first diagnosis for endometriosis within these groups were standardised by the indirect method. ${ }^{2}$ 


\section{Results}

Up to the end of 1990,313 women had had endometriosis diagnosed at laparoscopy (41) or laparotomy (272). Endometriosis was the principal diagnosis in 142 women and an additional diagnosis in 171 . We decided to focus on the women with endometriosis as the principal diagnosis since this group would be least influenced by selection bias. For example, uterine fibromyomata was the principal diagnosis in almost half $(47 \%)$ of the women in whom endometriosis was an additional diagnosis. We also omitted the four women who were infertile as a result of endometriosis because we were specially interested in the influence of birth control methods on endometriosis. Although the results presented here are limited to 138 women, analyses conducted on the total of 313 women gave similar results (not shown).

Table I shows the effect of age on risk of endometriosis. Endometriosis rates increased sharply from age group 25-29 to 40-44 and then began to fall. Parity was not significantly related to endometriosis (table II). However, if the four women with infertility were included, all of whom were nulliparous, the negative linear trend became significant at the $2 \%$ level. Social class, cigarette smoking, and obesity were unrelated to endometriosis (data not shown).

TABLE I-Rate of endometriosis in women attending family planning clinics by age

\begin{tabular}{lccc}
\hline $\begin{array}{l}\text { Age group } \\
\text { (years) }\end{array}$ & $\begin{array}{c}\text { No of } \\
\text { cases }\end{array}$ & $\begin{array}{c}\text { Rate per } 1000 \\
\text { woman years }\end{array}$ & $\begin{array}{c}\text { Relative risk } \\
(95 \% \text { confidence interval) }\end{array}$ \\
\hline $25-29$ & 3 & $0 \cdot 13$ & $1 \cdot 0$ \\
$30-34$ & 14 & $0 \cdot 28$ & $2 \cdot 1(0 \cdot 6$ to $11 \cdot 4)$ \\
$35-39$ & 42 & $0 \cdot 60$ & $4 \cdot 5(1 \cdot 5$ to $22 \cdot 9)$ \\
$40-44$ & 58 & $0 \cdot 81$ & $6 \cdot 1(2 \cdot 0$ to $30 \cdot 6)$ \\
$45-49$ & 18 & 0.51 & $3 \cdot 9(1 \cdot 1$ to $20 \cdot 7)$ \\
$\geqslant 50$ & 3 & $0 \cdot 14$ & $1 \cdot 1(0 \cdot 1-8 \cdot 2)$ \\
\hline
\end{tabular}

${ }^{\star}$ Standardised for parity. $\chi^{2}$ for heterogeneity $=30 \cdot 9(p<0 \cdot 001)$.

TABLE II-Effect of parity on rate of endometriosis in women attending family planning clinics

\begin{tabular}{lccc}
\hline $\begin{array}{l}\text { No of still } \\
\text { births and live } \\
\text { births }\end{array}$ & $\begin{array}{c}\text { No of } \\
\text { cases }\end{array}$ & $\begin{array}{c}\text { Rate per } 1000 \\
\text { woman years }\end{array}$ & $\begin{array}{c}\text { Relative risk } \\
(95 \% \text { confidence interval })^{\star}\end{array}$ \\
\hline 0 & 11 & 0.57 & $1 \cdot 0$ \\
1 & 25 & 0.70 & $1 \cdot 2(0.6$ to $2 \cdot 8)$ \\
2 & 66 & 0.50 & $0.9(0.5$ to $1 \cdot 8)$ \\
3 & 26 & 0.43 & $0 \cdot 8(0.4$ to $1 \cdot 7)$ \\
$\geqslant 4$ & 10 & 0.40 & $0.7(0.3$ to $1 \cdot 8)$ \\
\hline * Standardised for age. $\chi^{2}$ for linear trend $=2 \cdot 7(p=0 \cdot 10)$.
\end{tabular}

Table III shows the association between the interval since last pregnancy and endometriosis. Although the numbers are small, there were similar rates of endometriosis in the never pregnant and in the unknown category, low rates in pregnant women and in the 48 months following pregnancy, and then higher rates once again in the remaining groups. The trend was, however, not significant. The date of last pregnancy was not known in some women because the dates of spontaneous and induced abortions and of ectopic

TABLE III-Relation between endometriosis and interval since last pregnancy

\begin{tabular}{|c|c|c|c|}
\hline & $\begin{array}{l}\text { No of } \\
\text { cases }\end{array}$ & $\begin{array}{l}\text { Rate per } 1000 \\
\text { woman years }\end{array}$ & $\begin{array}{l}\text { Relative risk } \\
(95 \% \text { confidence } \\
\text { interval })^{\star}\end{array}$ \\
\hline Never pregnant & 11 & 0.59 & $1 \cdot 0$ \\
\hline Pregnant & 1 & $0 \cdot 28$ & $0.5(0.0$ to 3.2$)$ \\
\hline \multicolumn{4}{|c|}{ Interval since last pregnancy (months) } \\
\hline Not known & 20 & 0.64 & $1.1(0.5$ to 2.5$)$ \\
\hline$\leqslant 24$ & 3 & 0.25 & $0.4(0.1$ to 1.6$)$ \\
\hline $25-48$ & 5 & 0.35 & $0.6(0.2$ to 1.9$)$ \\
\hline $49-72$ & 13 & $0 \cdot 73$ & $1.2(0.5$ to 3.1$)$ \\
\hline $73-96$ & 9 & 0.42 & $0.7(0.3$ to 1.9$)$ \\
\hline $97-120$ & 13 & 0.52 & $0.9(0.4$ to 2.2$)$ \\
\hline$\geqslant 121$ & 63 & $0 \cdot 49$ & $0.8(0.5$ to 1.7$)$ \\
\hline
\end{tabular}

* Standardised for age and parity. $x^{2}$ for heterogeneity $=6 \cdot 2(p=0 \cdot 6)$
TABLE IV-Effect of taking oral contraceptives on rate of endometriosis

\begin{tabular}{|c|c|c|c|}
\hline & $\begin{array}{l}\text { No of } \\
\text { cases }\end{array}$ & $\begin{array}{l}\text { Rate per } 1000 \\
\text { woman years }\end{array}$ & $\begin{array}{c}\text { Relative risk } \\
(95 \% \text { confidence interval) }\end{array}$ \\
\hline \multicolumn{4}{|c|}{ Total duration of use (months): ${ }^{\star}$} \\
\hline Nevert & 47 & $0 \cdot 47$ & $1 \cdot 0$ \\
\hline$\leqslant 12$ & 4 & $0 \cdot 43$ & $0.9(0 \cdot 2$ to $2 \cdot 5)$ \\
\hline $13-24$ & 6 & 0.54 & $1.2(0.4$ to 2.7$)$ \\
\hline $25-48$ & 16 & 0.56 & $1.2(0.6$ to $2 \cdot 1)$ \\
\hline $49-72$ & 24 & $0 \cdot 73$ & $1.6(0.9$ to 2.6$)$ \\
\hline $73-96$ & 18 & 0.62 & $1.3(0.7$ to 2.3$)$ \\
\hline$\geqslant 97$ & 23 & 0.38 & $0.8(0.5$ to 1.3$)$ \\
\hline \multicolumn{4}{|c|}{ Interval since last taken (months): $\ddagger$} \\
\hline Never taken $\dagger$ & 47 & 0.47 & $1 \cdot 0$ \\
\hline $0-125$ & 11 & $0 \cdot 18$ & $0.4(0.2$ to 0.7$)$ \\
\hline $13-24$ & 8 & 0.67 & $1.4(0.6$ to 3.0$)$ \\
\hline $25-48$ & 19 & 0.83 & $1.8(1.0$ to 3.1$)$ \\
\hline $49-72$ & 17 & $0 \cdot 79$ & $1.7(0.9$ to 3.0$)$ \\
\hline 73-96 & 12 & $0 \cdot 64$ & $1.4(0.7$ to $2 \cdot 6)$ \\
\hline$\geqslant 97$ & 24 & 0.68 & $1.5(0.8$ to 2.4$)$ \\
\hline
\end{tabular}

${ }^{\star}$ Standardised for age and parity. $x^{2}$ for linear trend $=0.0(p=1 \cdot 0)$.

†Contraceptive methods used by women who had never taken oral contraceptives were diaphragm $(29 \%)$, intrauterine device $(29 \%)$, condoms $(5 \%)$, female sterilisation $(14 \%)$, male sterilisation $(11 \%)$, none $(11 \%)$, and other methods $(1 \%)$

$\ddagger$ Standardised for age and parity. $\chi^{2}$ for heterogeneity $=24 \cdot 8(p<0 \cdot 001)$.

SIncludes women currently taking oral contraceptives.

TABLE $\mathrm{V}$-Endometriosis in relation to interval since last use of intrauterine device

\begin{tabular}{lrcc}
\hline $\begin{array}{l}\text { Interval since } \\
\text { last use (months) }\end{array}$ & $\begin{array}{c}\text { No of } \\
\text { cases }\end{array}$ & $\begin{array}{c}\text { Rate per } 1000 \\
\text { woman years }\end{array}$ & $\begin{array}{c}\text { Relative risk } \\
(95 \% \text { confidence interval) }\end{array}$ \\
\hline Nevert & 106 & 0.56 & $1 \cdot 0$ \\
$0-12 \ddagger$ & 10 & 0.22 & $0 \cdot 4(0 \cdot 2$ to $0 \cdot 7)$ \\
$13-24$ & 3 & 0.77 & $1 \cdot 4(0 \cdot 3$ to $4 \cdot 0)$ \\
$25-48$ & 2 & $0 \cdot 27$ & $0 \cdot 5(0 \cdot 1$ to $1 \cdot 8)$ \\
$49-72$ & 5 & $0 \cdot 77$ & $1 \cdot 4(0 \cdot 4$ to $3 \cdot 2)$ \\
$73-96$ & 4 & 0.69 & $1 \cdot 2(0 \cdot 3$ to $3 \cdot 2)$ \\
$\geqslant 97$ & 8 & $0 \cdot 66$ & $1 \cdot 2(0.5$ to $2 \cdot 3)$ \\
\hline
\end{tabular}

* Standardised for age and parity. $\chi^{2}$ for heterogeneity $=11.9(p=0.06)$

†Contraceptive methods used by women who had never used an intrauterine device were pill $(26 \%)$, diaphragm $(18 \%)$, condom $(11 \%)$, female sterilisation $(14 \%)$, male sterilisation $(16 \%)$, none $(14 \%)$, and other methods $(1 \%)$. ¥Includes current users.

pregnancies were not recorded before entry to the study.

Total duration of taking oral contraceptives was not related to the risk of endometriosis (table IV). Women who were currently taking the pill or who had stopped taking it in the last 12 months had a significantly lower rate of endometriosis than those who had stopped for longer periods. We combined current users and those who had stopped within 12 months for analysis in case some women had been directed to stop the pill before elective surgery. Rates of endometriosis were higher in those who had stopped taking the pill for over 12 months than in those who had never taken it. We therefore examined the reasons for stopping oral contraceptives among these women. Of the 80 women concerned, 28 stopped because of sterilisation, 12 because of headache, seven because of weight gain, five because they were anxious about side effects, four because of their age, four because they were planning pregnancy, and the remaining 20 for a variety of reasons. Only one woman had stopped oral contraceptives to await an operation.

We found no relation between endometriosis and total duration of use of intrauterine devices, but current users and recent users had a lower rate of endometriosis than non-users (table V). Women who had used intrauterine devices in the past had a slightly increased rate of endometriosis over never users. The reasons for removal of intrauterine devices were bleeding or pain in nine women, sterilisation in five, planning pregnancy in three, unplanned pregnancy in two, and other reasons in three. The apparent proective effect of current and recent use of intrauterine devices was not limited to any particular type of device (data not shown).

Table VI shows that duration since last use of the diaphragm had no effect on rates of endometriosis. Total length of use was also unrelated (data not shown). 
TABLE VI-Rate of endometriosis by interval since last use of diaphragm

\begin{tabular}{|c|c|c|c|}
\hline $\begin{array}{l}\text { Interval since } \\
\text { last use (months) }\end{array}$ & $\begin{array}{l}\text { No of } \\
\text { cases }\end{array}$ & $\begin{array}{l}\text { Rate per } 1000 \\
\text { woman years }\end{array}$ & $\begin{array}{c}\text { Relative risk } \\
(95 \% \text { confidence interval })^{\star}\end{array}$ \\
\hline Nevert & 93 & 0.51 & $1 \cdot 0$ \\
\hline $0-12$ & 20 & 0.46 & $0.9(0.5$ to 1.4$)$ \\
\hline $13-24$ & 2 & $0 \cdot 44$ & $0.9(0.1$ to 3.1$)$ \\
\hline $25-48$ & 4 & 0.47 & $0.9(0.2$ to 2.3$)$ \\
\hline $49-72$ & 3 & 0.38 & $0.8(0.2$ to 2.2$)$ \\
\hline $73-96$ & 5 & 0.72 & $1.4(0.4$ to 3.3$)$ \\
\hline$\geqslant 97$ & 11 & 0.62 & $1.2(0.6$ to 2.2$)$ \\
\hline
\end{tabular}

* Standardised for age and parity. $\chi^{2}$ for heterogeneity $=1 \cdot 6(p=1 \cdot 0)$.

†Contraceptive methods used by women who had never used the diaphragm were pill $(27 \%)$, intrauterine device $(20 \%)$, condom $(10 \%)$, female sterilisation $(15 \%)$, male sterilisation $(15 \%)$, none $(12 \%)$, and other methods $(1 \%)$.

\section{Discussion}

Any study of endometriosis is potentially biased because operative intervention (laparoscopy or laparotomy) is necessary to diagnose the condition, and selective factors may determine who has surgery. Despite this problem we found only the well known associations between endometriosis and age and parity. There was no association with social class or cigarette smoking as has been suggested elsewhere. ${ }^{13}$ Our data might have been less affected by bias than those in other studies because we considered only women in whom the primary diagnosis was endometriosis.

We were surprised that only four women with endometriosis had infertility. Discharge summaries and contraceptive histories confirmed this number. The explanation may be that older women who had often completed their families were recruited to the study. Alternatively, endometriosis may be an uncommon cause of infertility.

Our results suggest that endometriosis is less of a problem during pregnancy and the subsequent four years than it is at other times, although the finding was not significant. Total duration of oral contraceptive use was unimportant, but a very low rate of endometriosis was found among women currently or recently taking the pill compared with women who had never taken it or had stopped for over 12 months. Reasons for stopping the pill seemed unremarkable. We suggest that endometriosis is suppressed during current and recent pill use but that the disease subsequently emerges after the pill is stopped. This would give a pattern of low rates in current and recent takers followed by somewhat higher rates in former takers. A similar pattern of disease was noted in the Royal College of General Practitioners study (rate/1000 woman years 0.58 in non-takers, 0.29 in current takers, and 0.8 in former takers $)^{4}$ and in the Walnut Creek study (rates $0.97,0.60$, and 1.38 , respectively). ${ }^{5}$ Several other studies have found evidence suggesting that oral contraceptives protect against endometriosis. $^{6-8}$
INTRAUTERINE DEVICES

The results for intrauterine devices showed the same pattern as those for the pill, although smaller numbers reduce the significance. Other studies have shown intrauterine devices to have either no effect ${ }^{9}$ or a deleterious effect ${ }^{7}$ on endometriosis. It seems unlikely that an intrauterine device would suppress the symptoms of endometriosis, and we suspect that many women with a device who develop the clinical features of endometriosis (pain, bleeding, palpable pelvic masses) are treated by removal of the device rather than by laparoscopy or laparotomy. The symptoms of some women would improve after removal of the device whatever the underlying condition and it might be months or years later that recurrence of the symptoms would lead to diagnosis of endometriosis. Nine out of 22 former users of intrauterine devices had had them removed because of bleeding or pain. If all these subjects had had endometriosis at the time of removal the rate in current and recent users would rise to 0.42 per 1000 woman years (from $0 \cdot 22$ ) and the relative risk would be non-significant at $0 \cdot 7$ (from 0.4 ).

In conclusion, we suspect that neither oral contraceptives nor intrauterine devices have any long term effect on the risk of endometriosis. Oral contraceptives may mask the symptoms of the disease but it emerges after the preparations are stopped. With regard to intrauterine devices we suggest that in some women developing endometriosis while using them the disease goes unrecognised and they are treated by removal of the device. As with oral contraceptives, the disease then emerges in former users.

We thank Mrs P Brown, Mrs D Collinge, Mrs J Winfield, our research assistants, and the doctors and nurses working in the participating clinics for their continued loyal support. We also thank the Medical Research Council, the Imperial Cancer Research Fund, and the Knott Family Trust for financial support.

1 Cramer DW, Wilson E, Stillman RJ, Bergen MJ, Belisle S, Schiff I, et al. The relation of endometriosis to menstrual characteristics, smoking, and exercise. IAMA 1986:255:1904-8.

2 Vessey MP, Doll R, Peto R, Johnson B, Wiggins $\mathrm{P}$. A long term follow up study

of women using different methods of contraception: an interim report. of women using different

3 Obermeyer CM, Armenian HK, Azoury R. Endometriosis in Lebanon. A casecontrol study. Am $\mathcal{G}$ Epidemiol 1986;124:762-7.

4 Royal College of General Practitioners. Oral contraceptives and health: an interim report from the oral contraceptive study of the Royal College of General Practitioners. London: Pitman Medical Publishing, 1974.

5 Ramcharan S, Pellegrin FA, Ray R, Hsu J-P. The Walnut Creek contraceptive drug study: a prospective study of the side effects of oral contraceptives. Vol III. Bethesda: National Institutes of Health, 1981. (Center for Population Research Monograph, Publication No 81-564.)

6 ButtramVC. Cyclic use of combination oral contraceptives and the severity of endometriosis. Fertil Steril 1979;31:347-8.

7 Kirshon B, Poindexter AN. Contraception: a risk factor for endometriosis. Obstet Gynecol 1988;71:829-31.

8 Mahmood TA, Templeton A. Prevalence and genesis of endometriosis. Hum Reprod 1991;6:544-9.

9 Moen MH. Endometriosis in women at interval sterilization. Acta Obstet Gynecol Scand 1987;66:451-4.

(Accepted 17 November 1991)

\section{ONE HUNDRED YEARS AGO}

\section{HYPNOTISM AND THE DIVORCE COURT}

In a case tried before Mr. Justice Barnes last week in the Divorce Court on a petition for judicial separation by the wife by reason of the adultery of the husband, there was some remarkable evidence in which hypnotism played a prominent part. It was stated in evidence that a young girl whom the defendant had rescued was invited to the house. Whilst there the husband became very familiar with the girl. They used to read books, and he studied hypnotism; in fact, "hypnotism was going on all day long." Theosophy came on the scene also, and somnambulism. The "Mahatma" was alleged to have told the hypnotising husband that "he was wrongly united." Perhaps after this it is not surprising that the matter ended in the Divorce Court and with a decree of judicial separation. Such results of hypnotic influence have already been referred to in these columns in the papers which we have published on the subject from a well-known pen; and, indeed, are admitted as evident and recognised facts by the warmest advocates of this very doubtful practice. Therapeutically the value of hypnotism is obviously but slight and occasional; its moral and social perils are certain and serious.

(BMF 1893;i;:655) 